\title{
Type 2 diabetes: New anti-diabetics and therapeutic strategy for military pilots and planes, combat vehicles and warship crews
}

\author{
Lisbona Gil A. ${ }^{1}$, Vicente-Arche Navarro A. ${ }^{2}$, Ríos Tejada F. ${ }^{3}$, Molina Valverde JM. ${ }^{4}$, \\ Alonso Rodríguez C. ${ }^{5}$
}

Sanid. mil. 2014; 70 (4): 282-287; ISSN: 1887-8571

\begin{abstract}
SUMMARY
The training of combat, transport or helicopter pilots and flight, combat vehicles and warship crews imply a big effort in terms of economic resources, time and logistics for our Armed Forces (FAS). Therefore, it is the responsibility of the Military Health Service to maintain the aptitudes and the skills of our personnel in the best possible conditions for the longest period of time, thus procuring the maximum operating capacity required for the accomplishment of their missions. In this paper it is reviewed and proposed antidiabetic drugs that may be safely used by pilots, flight, combat vehicles and warship crews, appreciating those that do not produce hypoglycemia neither cause side effects that can compromise the operating capacity. It is recommended and encouraged personnel with pre-diabetic condition to modify their life style and to initiate treatment with metformin, in order to delay or to avoid the onset of diabetes and extend their operating life. It is also encouraged the use of those anti-diabetic agents that best preserve the function of the pancreatic beta cell, therefore delaying the need for insulin based therapy.
\end{abstract}

KEYWORDS: type 2 diabetes. Military pilots. Flight crews. Combat vehicles crews. Warship crews.

Diabetes tipo 2: nuevos antidiabéticos y estrategia terapéutica en pilotos militares, tripulaciones de aeronaves y vehículos de combate y dotaciones de buques de guerra

RESUMEN: la formación de un piloto de combate, transporte o helicóptero, tripulaciones de vuelo y vehículos de combate y dotaciones de buques de guerra, supone un gran esfuerzo en cuestión de recursos económicos, de tiempo y medios logísticos para nuestras Fuerzas Armadas (FAS). Por tanto, es responsabilidad de la Sanidad Militar velar por mantener en las mejores condiciones y durante el mayor tiempo posible las aptitudes y capacidades de nuestro personal de vuelo, vehículos de combate y embarcado, procurando así la máxima operatividad para el cumplimiento de las misiones que el mando pudiera requerir. En este artículo se hace una revisión y propuesta de aquellos fármacos antidiabéticos susceptibles de ser utilizados con seguridad por pilotos, tripulaciones de aeronaves y vehículos de combate y dotaciones de buques de guerra, valorando que no produzcan hipoglucemias ni causen efectos secundarios que comprometan la operatividad. Se recomienda y estimula a aquellos que presenten un estado prediabético a modificar su estilo de vida y tratamiento con metformina para retrasar o evitar la aparición de una diabetes prolongando su vida operativa. Se estimula a quienes presenten una diabetes tipo 2 la utilización de aquellos antidiabéticos que mejor preserven la función de la célula beta para retrasar la necesidad de tratamiento insulínico.

PALABRAS CLAVE: Diabetes tipo 2. Pilotos militares. Tripulaciones de vuelo. Tripulaciones de vehículos de combate. Dotaciones de buques de guerra.

\section{INTRODUCTION}

The training of combat, transport or helicopter pilots and flight, combat vehicles and warship crews imply a big effort in terms of economic resources, time and logistics for our Armed Forces (FAS). Therefore, it is the responsibility of the Military Health Service to maintain the aptitudes and the skills of our

${ }^{1}$ Lt. Col. Physician. Central Defense Hospital Gómez Ulla. Endocrinology and Nutrition Service. Madrid.

${ }^{2}$ Lt. Physician. Aerospace Medicine Training Center. Madrid.

${ }^{3}$ Col. Physician. Aerospace Medicine Training Center. Madrid.

${ }^{4}$ Gen. Physician. General Headquarters of the Navy. Madrid.

${ }^{5}$ Gen. Physician. General Air Force Headquarters. Madrid.

Spain.

Correspondence: Arturo Lisbona Gil. alisgil@oc.mde.es

Recibido: 4 de marzo de 2014

Aceptado: 18 de junio de 2014 personnel in the best possible conditions for the longest period of time, thus procuring the maximum operating capacity required for the accomplishment of their missions.

Type 2 Diabetes (DM2) is a metabolic disease characterized by elevated blood glucose levels due to insulin resistance or its inadequate secretion that leads to the long-term development of micro and macrovascular complications. In addition to insulin resistance and secretion deficit, other factors such as appetite, gastric emptying, carbohydrate absorption, incretin effect, hepatic glucose production, glucagon and amylin secretion and renal excretion of glucose, contribute to the hyperglycemic state, which therefore makes them therapeutic targets to achieve the normalization of blood glucose levels ${ }^{1}$.

The prevalence of diabetes in the Spanish general population aged $>18$ is approximately $13.8 \%$, with nearly half unrecognized cases $(6 \%)$. Regarding pre-diabetic conditions, the prevalence of impaired fasting glucose (IFG) in the same 
population is $3.4 \%$, while impaired glucose tolerance (IGT) accounts for $9.2 \%$. The prevalence of cases with combination of these two conditions is $2.2 \%$. In general, in Spain, disorders related to carbohydrate metabolism account for about $28 \%$ of the population studied. Another particularly relevant data is that the prevalence of DM2 increases with age ${ }^{2}$. Being the most prevalent form of diabetes, DM2 affects people of any social group, including pilots. The prevalence of diabetes and other cardiovascular risk factors is found to be lower in pilots than in the general population due to rigorous initial medical tests and to maintaining healthier lifestyles ${ }^{3,4}$. DM2 prevalence in a group of 762 Spanish pilots was $1 \%$, while of the impaired fasting glucose was $19.7 \%$. Type 2 DM doesn't tend to produce ketosis, but this complication may arise in situations of stress and therefore cause acute incapacitation of pilots. One one hand, the side effects of drugs used to control the disease can make them incompatible with the safety requirements, while on the other, micro and macrovascular complications arising from inadequate glycemic control and duration of disease lead to the reduction of operating life of a pilot, flight, combat vehicles and warship crews.

Pre-diabetic conditions (IFG, IGT, HbA1c 5.7-6.4\%) bear a high relative risk for developing type 2 diabetes. Recognizing them gives us a great advantage when implementing lifestyle modifications and pharmacologic measures to prevent the occurrence of DM2 in pilots, air and warships crews. If we intend to keep our troops in the best condition for as long as possible, it is highly recommended to implement these measures from the start of the first biochemical detection of glucose level alterations. Changes in lifestyle such as regular exercise (at least 150 $\mathrm{min} /$ week of moderate exercise) and 7\% loss of body weight can prevent conversion of IFG to DM2 in up to $50 \%$ of the cases, although maintaining such measures for a long period of time is highly complicated, and there is no scientific evidence of their long-term effects. The American Diabetes Association (ADA) recommends the use of metformin to prevent or delay the onset of diabetes ${ }^{6}$. Therefore, it would be justified to use metformin in pre-diabetic conditions in order to delay progression to diabetes, extending the operational lifecycle of ship-borne and airborne personnel and combat vehicles crews, and maintaining their skills and aptitudes at its best condition and for as longest time possible.

\section{CURRENT AERONAUTICS LEGISLATION}

In regards to current regulations, may any anti-diabetic be used? The truth is that we cannot give a clear answer on this subject, since regulations depend on their field of application. The only point where there seems to be a certain legislative homogeneity is in the use of insulin and secretagogues, both capable of producing hypoglycemia, which disqualifies them for the issuance of flight licenses (except in the United Kingdom). For DM2 cases that do not require insulin for its proper control, there are different stands according to the legislative body.

In Spanish civil aviation, regulations in this regard are based on the norms published in the Official Journal of the European Union (EU Regulation No. 1178/2011)7:
1. "Applicants with diabetes requiring insulin will be qualified as unfit."

2. In Aeromedical evaluation; "Applicants for a Class 1 medical certificate requiring medication other than insulin to control blood sugar will be derived to the authority empowered to issue licenses."

For the latter case, the decision making authority may refer to the Acceptable Means of Compliance (AMC's), written by European Aviation Safety Agency (EASA), among these we find:

"The use of anti-diabetic medications that are not likely to cause hypoglycemia may be acceptable for a fit assessment with a multi-pilot limitation"s.

This means that the EASA allows the expedition of licenses on the condition that the pilot is always accompanied by a copilot (special multicrewed license, OML). In addition, it expands the therapeutic range, allowing the use of medication beyond from those traditionally used, such as biguanides.

Currently, there are two radically opposed stands in terms of civil aviation regulation: the American (Air Force Waiver Guide) and that of the United Kingdom (UKCAA). The American regulation, much more stringent, prohibits the use of all oral antidiabetic drugs except metformin, in which case the expedition of OML is required ${ }^{9}$. On the other side, according to the UKCAA Guidance Material, pilots could be considered fit for flying with any type of insulin or anti-diabetic as long as they are able to carry a good glycemic control and perform obligatory glycemic monitoring (prior, during and after the flight) and a as long as multicrew flight limitation is respected ${ }^{10}$.

What happens in the Spanish military field? To answer that, we should refer to the Ministerial Order 23/2011 11 that establishes the rules for the assessment of the medical aptitude for Armed Forces personnel with flight responsibility, which states (Annex 1, section 183.b):

GENERAL NORM: "Those who exhibit non-insulin-dependent diabetes mellitus (type 2) requiring medication that produces hypoglycemia or other symptoms that might interfere with the operating capacity, will be qualified as unfit".

Section 199 completes this rule:

PERIODICAL CHECK UP: Those who exhibit non-insulin-dependent diabetes mellitus controlled with dietetic measures or with medication with no risk of hypoglycemia or causing symptoms that might decrease the operating capacity, might be qualified as fit. This section shall not apply to fighter pilots, whose medical aptitude should be assessed according to the General Rule.

On one hand, General Rule qualifies as unfit those with DM2 on treatment with oral anti-diabetics that produce hypoglycemia or other symptoms interfering with the operating capacity, while on the other, it declares fit those with DM2 treated with medication with no risk of hypoglycemia or other potentially harmful symptoms. We consider those statements the same, as they both allow the use of anti-diabetics as long as they present a proven security of not causing hypoglycemia nor other important symptoms that interfere with the operational fitness. As a matter of fact, this regulation permits the use of oral anti-diabetic drugs even in fighter pilots since their "medical aptitude should be assessed according to the General Rule" and this rule excludes only 
those pilots who require medicines that cause hypoglycemias and other symptoms, but not those who benefit from ADOs with no such side effects.

\section{OBJECTIVES}

The objectives of this paper are:

1. To review and propose anti-diabetic drugs that may be safely used by pilots, flight, combat vehicles and warship crews, based on current regulations in Spain and other countries, as well as on the scientific evidence of diabetes treatment. This could be defined as those that: 1) do not produce hypoglycemia; 2) do not cause side effects that can compromise the operating capacity.

2. To recommend and encourage personnel with pre-diabetic condition to modify their life style and to initiate treatment with metformin, in order to delay or to avoid the onset of diabetes and extend their operating life.

3. To encourage the use of those anti-diabetic agents that best preserve the function of the pancreatic beta cell, therefore delaying the need for insulin based therapy.

4. To recommend anti-diabetics that present the best tolerance and no risk of hypoglycemia.

\section{CURRENT THERAPEUTIC ARSENAL}

Metformin: Oral insulin-sensitizing agent that reduces liver glucose production through the stimulation of an AMP protein kinase, increases the action of insulin and reduces intestinal absorption of glucose. Metformin does not cause weight gain (if at all, it might produce slight weight reduction), rarely produces hypoglycemia and in a UKPDS study its use led to a reduction of cardiovascular events and mortality rate. The most important side effects are diarrhea that is often urgent, gastrointestinal discomfort and alterations in gustatory perception. These effects are more frequent when initial doses are high, which is why it is recommended to start the treatment with low doses, increasing up gradually to the maximum tolerated dose. Metformin is contraindicated in cases of impaired renal function due to the risk of lactic acidosis, whose occurrence is rare, but it might jeopardize patient's life. Other conditions that in combination with metformin use might lead to lactic acidosis are hypoxaemia, sepsis, alcohol abuse, liver failure, myocardial infarction and shock. In these situations, the treatment with metformin should be suspen$\operatorname{ded}^{12,13}$. Its use would be fully authorized in pilots, flight, combat vehicles and warship crews with good tolerance to metformin.

Sulfonylureas: They stimulate insulin secretion from pancreatic $\beta$-cells by binding to the specific receptor on the ATPsensitive potassium channel (KATP) and inducing its closure. Insulin-sensitizers, such as metformin or the thiazolidinediones may have prolonged efficacy compared to sulfonylureas, since pancreatic reserve is depleted in patients with diabetes of long duration. The tolerance of these drugs is good but its use is associated with a slight weight increase, and given that the stimulation of insulin secretion is not glucose dependent, they can cause hypoglycemia, sometimes serious. The risk of hypoglycemia with long-acting sulfonylureas such as glibenclamide, is greater than with short-acting ones, such as glipizide. Sulfonylureas like the gliclazide have demonstrated low incidence of hypoglycemia (ACCORD) $)^{1,12,13}$. Given the possibility to induce hypoglycemia, their use would not be allowed in pilots, flight, combat vehicles and warship crews.

Meglitinides: They are secretagogues whose mechanism of action closely resembles that of the sulfonylureas, with less potential for hypoglycemia and shorter action, but greater efficacy in the postprandial period. Since their main elimination route is biliary, both available agents -repaglinide and nateglinide- can be used in patients with impaired renal function. Because of the short meglitinides set of action, a dose should be administrated immediately before a meal ${ }^{1,12,13}$. Due to the significant hypoglycemic potential, their use would not be allowed in pilots, flight, combat vehicles and warship crews.

Thiazolidinediones: They are insulin-sensitizers and therefore hypoglycemia does not pose a risk when thiazolidinediones are taken as monotherapy. They bind to PPAR $\gamma$ receptors, enhancing insulin sensitivity in both muscle and adipose tissue and inhibiting hepatic glucose production. The only agent in this drug class approved in Spain and in the EU is pioglitazone, due to the withdrawal of the rosiglitazone for its association with myocardial infarction. Pioglitazone has a favorable effect on lipid metabolism, increasing HDL-cholesterol and lowering triglyceride levels. Cardiovascular protective qualities of pioglitazone have been observed in PROactive study, together with fluid retention potential and increased heart failure risk, especially in patients with terminal renal failure. Given these properties, pioglitazone is contraindicated in patients with heart failure. Significant weight gain has been reported for all thiazolidinediones, together with increased risk of fractures in women and recently observed increased risk of bladder carcinoma ${ }^{1,12,13}$. These drugs conserve pancreatic function longer than any other anti-diabetic agent ${ }^{14}$, for what they are, along with metformin, the best therapeutic choice to lengthen the operating life of pilots, flight, combat vehicles and warship crews.

$\boldsymbol{\alpha}$-glucosidase inhibitors: They inhibit intestinal $\alpha$-glucosidase , enzyme that hydrolyzes carbohydrates, reducing the rate of their digestion and consequently, absorption. Two drugs belong to this therapeutic group, acarbose and miglitol. Administered orally, they both decrease postprandial glucose levels and, in a more discreet way, hemoglobin A1C level, not producing hypoglycemias. They often cause gastrointestinal side effects such as flatulence ${ }^{1,12,13}$. This side effect might possibly limit their use in airborne personnel due to significant pressure changes to which these individuals are subjected, while they are probably better tolerated by ship-borne personnel and combat vehicles crews.

Dipeptidyl peptidase-4 inhibitors (iDPP-4): These agents prevent the degradation of the endogenous incretin hormones glucagon-like peptide-1 (GLP 1) and glucose-dependent insulinotopic hormone (GIP), modestly increasing their circulating concentrations. They belong to the group of the incretin-mimetics. The $\beta$ cells insulin secretion increases, while the glucagon production by cells $\alpha$ is suppressed in a glucose-dependent manner, meaning that the insulin secretion is stimulated only in the state of hyperglycemia. Since the glucose - lowering effects are greater in the postprandial period and lower during the fasting, 
there is minimal risk of hypoglycemia. Along with metformin, these drugs are the easiest to use among all anti-diabetic agents, although their price is high. They have a neutral effect on body weight; the administration is oral, usually once a day and gastrointestinal and general tolerance are excellent, although there are reports of serious side effects such is acute pancreatitis and pancreatic cancer ${ }^{1,12,13}$. Both the U. S. Food and Drug Administration (FDA) and the European Medicines Agency (EMA) have analyzed a large amount of data on the safety of incretinmimetics, concluding that the data is conflicting in regards to a possible causal relationship between acute pancreatitis and pancreatic cancer and iDPP-4 use ${ }^{15}$. Drugs currently available in the Spanish market are sitagliptin, vildapliptin, saxagliptin and linagliptin, while alogliptin is still awaiting commercialization. In cardiovascular safety studies, the use of saxagliptin and alogliptin did not increase the incidence of cardiovascular events ${ }^{16,17}$. For their good tolerance they are, after metformin, the next best therapeutic option for DM2 in pilots, flight, combat vehicles and warship crews.

GLP-1 agonists (GLP-1): These drugs are also classified as "incretin mimetics", but, unlike the iDPP-4, they are injectable. Although their structure is similar to that of GLP-1, they exhibit increased resistance to DPP-4 degradation. They increase insulin secretion while inhibiting glucagon release, but only when glucose levels are increased thus reducing the likelihood of hypoglycemia. Weight loss, nausea and occasional vomiting and diarrhea, are results of slowing down gastric emptying and central suppression of appetite. However, the suspension of treatment is rarely required. GLP-1 agonists available at present are exenatide, liraglutide and lisixenatide. The first one requires administration twice a day due to its short action, while the long acting liraglutide and lisixenatide are administered once daily. A weekly injection of prolonged action exenatide is also available, and a monthly formulation is undergoing clinical testing. GLP-1 agonists are more potent than DPP-4 inhibitors reducing $\mathrm{HbAlc}$, although a concern exists about their potential to induce pancreatitis and, in the case of liraglutide, medullary thyroid carcinoma, and the latter as a result of thyroid C-cells hyperplasia observed in mice treated with it. Despite their beneficial effects on blood pressure and lipid metabolism, cardiovascular and long-term safety of GLP-1 agonists is unknown and their its cost is high ${ }^{1,12,13}$. Gastrointestinal side effects would make them unsuitable for use in fighter pilots, but their tolerance might be superior in non-fighter pilots, flight, combat vehicles and warship crews.

Bile acid sequestrants: Colesevelam is a second line treatment for hypercholesterolemia in patients with intolerance to statins that has the ability to reduce plasma glucose levels by an unknown mechanism. In spite of being approved by the FDA for use as a hypoglycemic drug, given its characteristics it is rather used for control of hyperlipidemia in diabetic patients. It is an expensive drug, with the constipation as the most relevant side effect ${ }^{1,12,13}$. It could be used in pilots and in flight, ship and combat vehicles crews, although its effect on glycemic control is poor.

Dopamine agonists: Bromocriptine has recently been approved for the treatment of type 2 diabetes. It is thought to act at the hypothalamic level, restoring the altered circadian rhythm that leads to insulin resistance and therefore increasing insulin sensi- tivity. Hypoglycemia doesn't occur and the most important side effects are dizziness and lightheadedness, nausea, fatigue, and rhinitis. The long-term side effects are unknown, but the association of prolonged treatment with dopamine agonists and an increased risk of valvular heart disease has been described ${ }^{1,12,13}$. Although their tolerance in pilots is not clear, the side effects described above together with poor potential of bromocriptine to reduce $\mathrm{HbA} 1 \mathrm{C}$ levels, make this therapeutic group little adequate, but not totally inconvenient for use in pilots, flight, warship and combat vehicles crews.

Amylin mimetics: Pramlintide is an injectable amylin-mimetic that stimulates amylin receptors. Amilyn is a hormone synthesized in $\beta$ pancreatic cells and co-secreted with insulin. It slows gastric emptying, increases satiety and suppresses the secretion of glucagon. It reduces body weight and doesn't produce hypoglycemia ${ }^{1,12,13}$. It's potential to reduce HbA1C levels is poor and it is not available in Spain.

Sodium-glucose co-transporter 2 (SGLT2) inhibitors: They constitute a new pharmacological group for the treatment of hyperglycemia in patients with type 2 diabetes. They act at the level of the renal proximal tubule, inhibiting the glucose reabsorption and therefore increasing glycosuria. The degree of glycosuria will depend on the glomerular filtration rate, decreasing as kidney function declines. They are orally administrated and, due to its mechanism of action, they do not produce hypoglycemia. The most developed and the only marketed drug from this group in Spain is dapaglifozin. Its main side effect is the increased risk of genitourinary infections ${ }^{18}$. This pharmacological group can be used in pilots, flight, warship and combat vehicles crews.

\section{CONTROL OBJECTIVES}

Intensive glycemic control reduces the risk of microvascular complications (retinopathy, nephropathy and neuropathy). Nevertheless, the effect of a strict glycemic control on the risk of macrovascular disease will depend on whether intensive glycemic control was initiated at the time of the diagnosis of diabetes in macrovascular disease-free stage or in long lasting diabetes, with macrovascular illness or cardiovascular risk factors present. In the first case, in the follow-up study of the UKPDS, 10 years after the completion of the study, patients who had been assigned to intensive control, had a lower risk of cardiovascular disease than those assigned to a conventional control (glycated hemoglobin $7 \%$ vs $7.9 \%$ ). In the second case, the three studies (ACCORD, ADVANCE, VADT), conducted in older patients with long lasting type 2 diabetes and with established vascular disease or with multiple cardiovascular risk factors, the strict glycemic control did not demonstrate a reduction neither in global nor in cardiovascular mortality ${ }^{1,19,20}$.

In addition to the time of the evolution of diabetes and the presence of cardiovascular disease, other factors like psychosocial considerations, the risk of hypoglycemia, the profession, life expectancy, serious coexisting diseases, advanced microvascular disease, and personal or public economic resources will also modify the control objectives. Although current guidelines set HbAlc $<7 \%$ or $6.5 \%$ as a goal, it is necessary to take into account the characteristics of each patient to identify the control 
objectives. Trying to reach glycated hemoglobin of $6 \%$ would be suitable for those highly motivated patients, with capacity of understanding and self-care, with personal or public resources, with a low hypoglycemic risk, short duration of diabetes, long life expectancy, without microvascular and macrovascular disease or other coexisting diseases. However, at the other extreme, i.e. in patients poorly motivated, with little capacity for understanding or self-care, with few personal or public resources, high risk of hypoglycemia, long lasting diabetes, short life expectancy, with established microvascular or macrovascular disease or other serious coexisting diseases, glycated hemoglobin of $8 \%$ may be adequate ${ }^{1,19,20}$.

As for the therapeutic objectives of glycemic control, in the US Air Force guidelines (USAF WAIVER), we can find strict requirements both in regards to the $\mathrm{HbAlc}$ that must be $<7 \%$, and to the blood pressure $(<130 / 80 \mathrm{mmHg})^{9}$, (Table 1). On the contrary, the guidelines in civil aviation of the United Kingdom (CAAUK) establish concentrations below $8.5 \%$ (10), (Table 2).

To ensure the absence of cardinal symptoms, polyuria, polydipsia, nocturia, etc, as a suitable control for the subjects we should consider glycated hemoglobin of $8 \%$, which would correspond to average blood glucose level of $183 \mathrm{mg} / \mathrm{dl}(10.2$ $\mathrm{mmol} / \mathrm{L})^{6}$. This proposal would be more permissive than the norms of the USAF WAIVER and somewhat more restrictive than the norms of the CAAUK.

\section{SECOND AND THIRD CHOICE DRUGS}

According to the recommendations of the American Diabetes Association (ADA) of 2014, if metformin is not contraindicated and it is well tolerated, it is the primary pharmacological agent in type 2 diabetes. If monotherapy with the maximum tolerated dose fails to achieve or to maintain the targeted goal of glycated hemoglobin $(<7 \%)$, it is necessary to add a second oral agent or a GLP-1 agonist or insulin 6 .

Pilots, flight and warship crews are special populations regarding the choice of a second or a third drug for type 2 diabetes control. The general rule for these populations would be that the second drug after metformin should be one of those that do not produce hypoglycemia, have the best tolerance and different mechanism of action. In this sense, the inhibitors of DPP-4 would have the best tolerance, although it should be taken into account that thiazolidinediones (pioglitazone) will be the ones to best preserve the function of pancreatic beta cells and therefore to effectively delay the need for insulin treatment. Sodiumglucose co-transporter 2 inhibitors would be also in the category of those that do not produce hypoglycemia and present a good tolerance, although current clinical experience is limited.

These populations would more likely use a third drug if two drugs fail to achieve an adequate glycemic control. In this way we would avoid or delay the insulin addiction and lengthen the operating life to pilots, flight and warship crews.

\section{CONCLUSIONS AND RECOMMENDATIONS OF TREATMENT (FIGURES 1 AND 2)}

1. In pre-diabetic conditions, the change of lifestyle, avoiding the overweight-obesity, increasing physical exercise and adding metformin, can prevent or delay the appearance of diabetes, thus extending the operating lifetime of pilots, flight and warship crews.

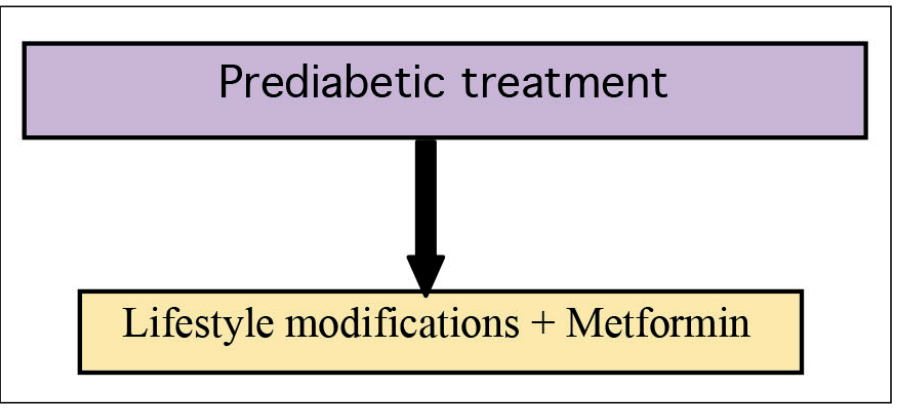

Figure 1. Treatment recommendations for pilots, flight, combat vehicles and ship crews with pre-diabetes.

Table 1. Definition of good control in type 2 diabetes (US AIR FORCE WAIVER).

*Good control is defined as listed below:

A. Fasting blood glucose $<126 \mathrm{mg} / \mathrm{dl}$ (report quarterly data points).

B. $\mathrm{Hb} \mathrm{Alc}<7 \%$ (report bi-annual data points unless therapy changed $w /$ in one year).

C. Lipid panel targeted to NCEP guidelines, currently LDL $<100 \mathrm{mg} / \mathrm{dL}$ (annual).

D. Blood pressure controlled to JNC guidelines, currently $<130 / 80 \mathrm{mmHg}$.

E. No diabetes-related complications that interfere with safety of flight / mission completion.

Table 2. Range of objectives in type 2 diabetes for pilots (CAAUK).

\begin{tabular}{|lccc|}
\hline Variable & Target & Review Treatment & Unfit \\
\hline HbAlc & $<8.5 \%(<69 \mathrm{mmol} / \mathrm{l})$ & $8.5-10 \%(69-86 \mathrm{mmol} / \mathrm{l})$ & $>10.0 \%(>86 \mathrm{mmol/l})$ \\
Systolic BP & $<140 \mathrm{mmHg}$ & $140-160 \mathrm{mmHg}$ & $>160 \mathrm{mmHg}$ \\
Diastolic BP & $<80 \mathrm{mmHg}$ & $80-95 \mathrm{mmHg}$ & $>95 \mathrm{mmHg}$ \\
Cholesterol & $4.0-4.5 \mathrm{mmol} / \mathrm{l}$ & $>4.5 \mathrm{mmol} / \mathrm{l}$ & $\mathrm{n} / \mathrm{a}$ \\
Triglycerides & $<2.5 \mathrm{mmol} / \mathrm{l}$ & $>2.5 \mathrm{mmol} / \mathrm{l}$ & $\mathrm{n} / \mathrm{a}$ \\
\hline
\end{tabular}


2. Insulin, sulfonylureas and meglitinides, would be officially contraindicated in these populations.

3. The GLP-1 agonists would be contraindicated in fighter pilots but may play a role in non-combat pilots, flight and warship crews.

4. $\alpha$-glucosidase inhibitors are possibly poorly tolerated by pilots and flight crews due to flatulence that arises in the situations of pressure changes, , although they might be tolerated by ship-borne personnel.

5. DPP-4 inhibitors, thiazolidinediones and SGLT2 inhibitors would be the most useful and the best tolerated in association with metformin and the most suitable to use in patients with metformin-intolerance.

6. Colesevelan and dopamine agonists may be useful for the association with other anti-diabetic agents in selected cases.

7. With regard to the control targets, we recommend glycated hemoglobin concentrations $\leq 8 \%$, that are closer to the CAAUK rules (HbA1c $<8.5 \%$, average blood glucose level of $196 \mathrm{mg} / \mathrm{dl})$, rather than the more restrictive US Air Force WAIVER (HbA1c $<7 \%$, average blood glucose level of $154 \mathrm{mg} / \mathrm{dl}$ or $8.6 \mathrm{mmol} / \mathrm{l})$.

\section{BIBLIOGRAPHY}

1. Ismail-Beigi F. Glycemic Management of Type 2 Diabetes Mellitus. N Engl J Med 2012;366:1319-27.

2. F. Soriguer, A. Goday, A. Bosch-Comas, E. Bordiú. Prevalence of diabetes mellitus and impaired glucose regulation in Spain: the Di@bet.es Study. Diabetologia 2012; 55:88-93.

3. Prevalence of cardiovascular disease risk factors among UK commercial pilots. Houston S; Mitchell S; Evans S, European Journal of Cardiovascular Prevention And Rehabilitation: Official Journal Of The European Society Of Cardiology, Working Groups On Epidemiology \& Prevention And Cardiac Rehabilitation And Exercise Physiology [Eur J Cardiovasc Prev Rehabil], ISSN: 1741-8275, 2011 Jun; Vol. 18 (3), pp. 510-7; Publisher: Sage; PMID: 21450633.

4. Butler GC, Nicholas JS. Health Among Airline Pilots. Air Line Pilot 2001; March:16.

5. Alonso Rodríguez $\mathrm{C}$, Medina Font $\mathrm{J}, \mathrm{Gu}-$ tierrez Ortega C. "Prevalencia de diabetes mellitus tipo 2 y de glucemia basal alterada en pilotos de aviación comercial". Medicina Aeroespacial y Ambiental Vol 4, $\mathrm{n}^{\circ}$ 6: 263267, 2006.

6. Standards of Medical Care in Diabetes-2014. American Diabetes Association. Diabetes Care 2014;37:S14-S80.

7. REGLAMENTO (UE) $\mathrm{N}^{\circ} 1178 / 2011 \mathrm{DE}$ LA COMISIÓN de 3 de noviembre de 2011 por el que se establecen requisitos técnicos y procedimientos administrativos relacionados con el personal de vuelo de la aviación civil en virtud del Reglamento (CE) n ${ }^{\circ}$ 216/2008 del Parlamento Europeo y del Consejo; Diario Oficial de la Unión Europea (versión Esp); 25-Nov-2011; p311/183-311/184.

8. AMC1 MED.B.025(g)(2). Acceptable Means of Compliance and Guidance Material; European Aviaton Safety Agency; 15-Dic-2011; p18. diabetes.
9. M. A. Gammill, D. V. Syoc; Air Force Waiver Guide; 28-may-2013; p291-298.

10. Diabetes certification Guidance v2.0; UK Civil Aviation Authority, Medical Department; Marzo-2013.

11. Orden Ministerial OM 23/2011, de 27 de abril de 2011 por la que se aprueban las normas para la valoración de la aptitud médica del personal de las Fuerzas Armadas con responsabilidad de vuelo; BOD núm. 88; 6-may-2011; Sección I, p11286-11288.

12. Qaseem A, Humphrey LL, Sweet DE, Starky M, Shekelle P. Oral Pharmacologyc Treatment of Type 2 Diabetes Mellitus: A Clinical Practice Guideline from the American College of Physicians. Ann Intern Med 2012;156:218-231

13. Garg R, Williams ME. Diabetes Management in the Kidney Patient. Med Clin N Am 97 (2013) 135-156

14. Kahn SE, Haffner SM, Heisse MA, Herman WH, Holman RR, Jones NP et al, for the ADOPT Study Group. Glycemic Durability of Rosiglitazone, Metformin or Glyburide Monotherapy. N Engl J Med 2006,355:2427-43

15. Egan AG, Blind B, Dundre K, de Graeff PA, Hummer T, Bourcier T, Rosebraugh C. Pancreatic Safety of Incretin-Based Drugs-FDA and EMA Assessment. N Engl J Med 2014; 370:794-797

16. Scirica BM, Deepak LB, Braunwald E, Steg PG, Davidson J, Hirshberg B, et al, for the SAVOR-TIMI 53 Steering Committee and Investigators. Saxagliptin and Cardiovascular Outcomes in Patients with Type 2 Diabetes Mellitus. N Engl J Med 2013;369:1317-1326

17. White WB, Cannon CP, Heller SR, Nissen SE, Bergenstal RM, Bakris GL, et al, for the EXAMINE Investigators. Alogliptin after Acute Coronary Syndrome in Patients with Type 2 Diabetes. N Engl J Med 2013;369:1327-1335

18. Chao EC, Henry RR. SLGT2 inhibition-a novel strategy for diabetes treatment. Nat Rev Drug Discov 2010;291:551-559

19. Ismail-Beigi F, Moghissi E, Tiktin M, Hirsch IB, Inzucchi SE, Genuth S. Individualizing Glycemic Targets in Type 2 Diabetes Mellitus: Implications of Recent Clinical Trials. Ann Intern Med 2011; 154:554-559

20. Inzucchi SE, Bergenstal RM, Buse JB, Diamant M, Ferrannini E, Nauck M, et al. Management of Hyperglycemia in Type 2 Diabetes: A Patient-Centered Approach. Position Statement of the American Diabetes Association (ADA) and the European Association for the Study of Diabetes (EASD). Diabetes Care 2012; 35:1364-79

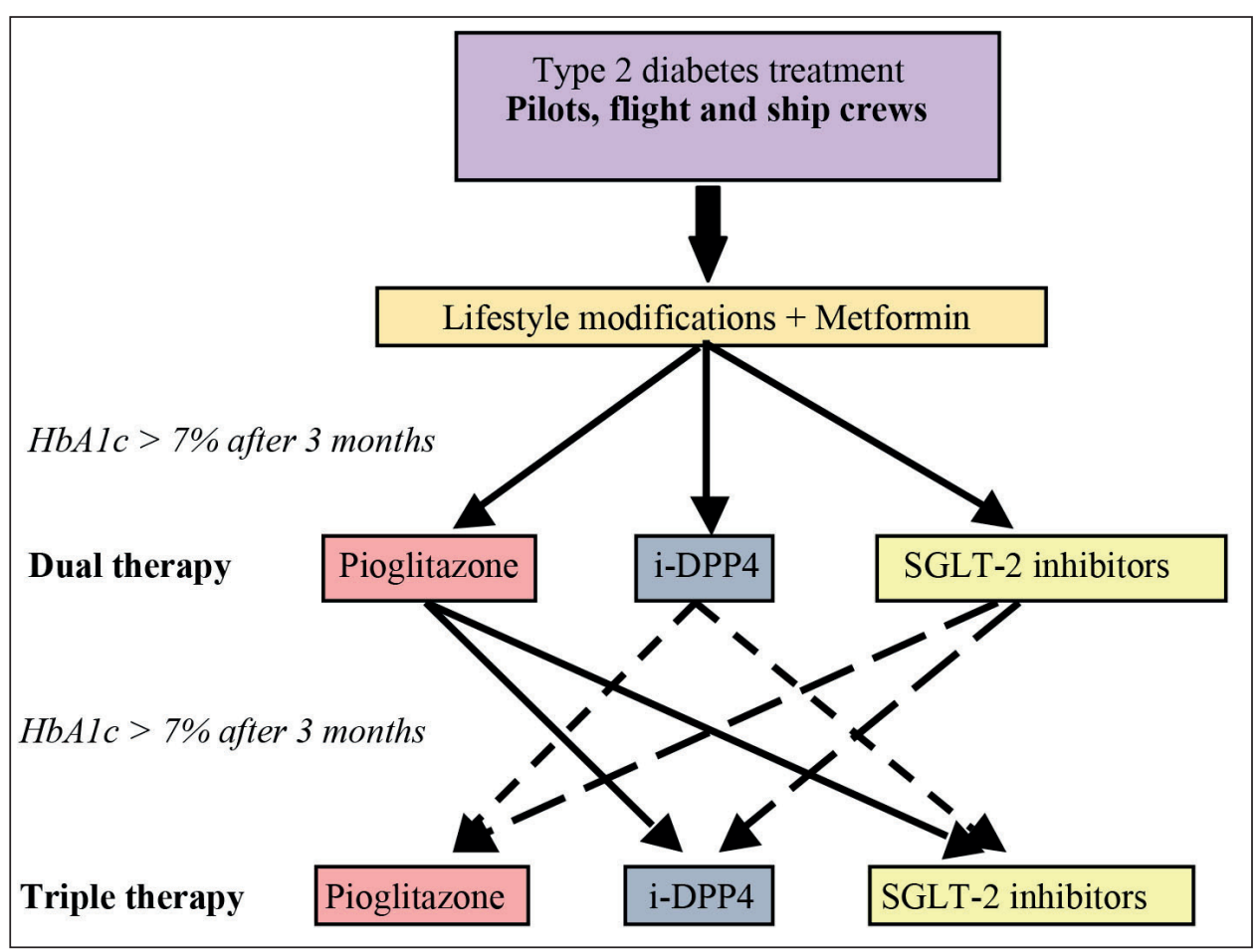

Figure 2. Treatment algorithm for pilots, flight, combat vehicles and ship crews with type 2 